INFORMASI: Kajian Ilmu Komunikasi-ISSN (p) o126-065o; ISSN (e) 2502-3837

Vol. 48. No. 2 (2018). Pp.181-194. doi: https://doi.org/10.21831/informasi.v48i2.22527

\title{
AUDIENCE AND PUBLIC SERVICE ADVERTISEMENT ABOUT THE DANGERS OF SMOKING
}

\author{
Awanis Akalili \\ awanisakalili@gmail.com \\ Universitas Gadjah Mada
}

\begin{abstract}
Public service advertisement which said "Berhentilah Menikmati Rokok Sebelum Rokok Menikmati Anda" is a warning the dangers of smoking which is aired on television. This advertisement is produced by the government to make smokers realize the dangers of smoking among young people especially students. However, this aim cannot be so easily achieved because the community nowadays is not a passive audience but it has moved into active audience. By taking four informants, this study tries to answer the question of how the student smokers among gang understand the advertising messages in public service advertisement which said "Berhentilah Menikmati Rokok Sebelum Rokok Menikmati Anda" on television. A reception analysis is chosen as the research method because this method can see how the audience understands the media messages based on the difference background they have. Based on the results of the study, it is found that four informants are able to negotiate with the advertising message on public service advertisement which said "Berhentilah Menikmati Rokok Sebelum Rokok Menikmati Anda". The four informants are able to understand the messages from that advertising by using their own point of view. The difference of meaning is affected by two things: the family environment and the existence as a gang member. Two informants receive the advertisement, while two other informants assume that the public service advertisement does not correspond to the reality.
\end{abstract}

Keywords: Reception Analysis, Gang Student, Smoking, Public Service Advertisement

\section{AUDIENS DAN IKLAN LAYANAN MASYARAKAT TENTANG BAHAYA MEROKOK}

\begin{abstract}
Abstrak
Iklan layanan masyarakat "Berhentilah Menikmati Rokok Sebelum Rokok Menikmati Anda" adalah peringatan bahaya merokok yang ditayangkan melalui televisi. Iklan ini diproduksi pemerintah dengan tujuan menyadarkan para perokok akan bahaya merokok, terutama kaum muda khususnya para pelajar. Hanya saja tujuan tersebut tidak bisa semudah itu dicapai karena saat ini masyarakat bukan kelompok penonton pasif tetapi sudah bergerak sebagai audiens aktif. Dengan mengambil empat informan, penelitian ini mencoba menjawab pertanyaan tentang bagaimana pelajar perokok di
\end{abstract}


lingkungan geng meresepsi pesan iklan dalam iklan layanan masyarakat "Berhentilah Menikmati Rokok Sebelum Rokok Menikmati Anda" di media televisi. Analisis resepsi sendiri dipilih sebagai metode penelitian karena metode ini melihat bagaimana audiens memahami pesan media berdasarkan perbedaan latar belakang yang dimiliki. Berdasar dari hasil penelitian, ditemukan fakta bahwa keempat informan mampu bernegosiasi dengan pesan iklan pada tayangan iklan layanan masyarakat "Berhentilah Menikmati Rokok Sebelum Rokok Menikmati Anda". Keempat informan mampu memahami pesan iklan yang disampaikan dengan sudut pandang mereka masing-masing. Perbedaan pemaknaan ini dipengaruhi oleh dua hal yaitu lingkungan keluarga dan keberadaan sebagai anggota geng. Dua informan menerima wacana yang di sampaikan, sementara dua informan lainnya menganggap tayangan iklan layanan masyarakat tersebut tidak sesuai dengan realitas.

\section{Kata Kunci: Analisis Resepsi, Pelajar Geng, Merokok, Iklan Layanan Masyarakat}

\section{PENDAHULUAN}

Audiens merupakan istilah kolektif dari penerima pesan dalam model proses komunikasi massa (Mc Quail, 1997). Komunikasi massa sendiri merupakan proses komunikasi pada khalayak luas melalui media massa seperti surat kabar, televisi, radio dan sebagainya (West\&Turner, 2007: 41). Audiens memiliki dua sifat yaitu pasif dan aktif. Audiens pasif adalah mereka yang menerima pesan yang disampaikan oleh media tanpa proses negosiasi. Sedangkan audiens aktif diartikan sebagai audiens yang mampu memilih media yang digunakan dan menerima pesan dengan proses negosiasi.

Salah satu contoh audiens adalah pelajar. Pelajar merupakan kaum muda yang bersifat dekat dengan media, labil emosi dan mudah terpengaruh lingkungan (Azca et.al, 2013). Lingkungan merupakan satu faktor yang paling mudah mempengaruhi bagaimana para pelajar dalam berperilaku salah satunya adalah lingkungan sekolah. Lingkungan sekolah dapat mempengaruhi pelajar dalam hal positif dan negatif. Pelajar yang bersifat labil emosi akan sangat mudah untuk masuk ke dalam lingkungan kelompok pelajar yang tidak baik, salah satunya masuk ke dalam kelompok geng (Azca et.al, 2013).

Geng didefinisikan sebagai kelompok anak muda, lebih dari dua orang yang melakukan aktivitas negatif seperti merokok, vandalisme, dan berkelahi dengan kelompok geng lainnya (Azca et.al, 2011: 195). Di Daerah Istimewa Yogyakarta (DIY) sebagai kota pelajar, fenomena geng sudah bukan hal yang baru. Tidak hanya geng di sekolahnya, pelajar ternyata juga mengikuti geng di luar sekolahnya(Supartiningsih,9Juni 2015). Fakta tersebut diperoleh peneliti dari wawancara singkat dengan Supartiningsih, salah satu konselor di PSBR (Panti Sosial Bina Remaja). PSBR sendiri adalah lembaga yang didirikan pemerintah DIY untuk menampung sekaligus merehabilitasi kaum muda terutama pelajar yang mengalami masalah dalam dirinya seperti putus sekolah, kecanduan merokok, narkoba, trauma semasa kecil, terkena kasus pidana seperti pembunuhan, penganiayaan, pemerkosaan dan pencurian (Supartiningsih \& Adiyaningsih, 9 Juni 2015).

Meski tidak ada data pasti berapa jumlah dan apa saja nama geng yang berasal dari lingkungan luar sekolah, menurut Supartiningsih ada beberapa geng yang muncul di luar lingkungan sekolah di seluruh Daerah Istimewa Yogyakarta (DIY) yaitu geng JOXZIN, QZRUH dan HUMORIEZT. Geng-geng tersebut umumnya berisi kaum muda yang beberapa di antaranya pelajar. Supartiningsih menjelaskan bahwa tidak hanya geng di sekolah, para pelajar juga mengikuti geng-geng di luar sekolah salah satunya geng HELLO KITTYyang merupakan geng beranggotakan para perempuan (Supartiningsih \& Adiyaningsih, 9 Juni 2015). Geng ini sempat menjadi topik hangat beberapa bulan lalu akibat penganiayaan yang dilakukan anggota geng terhadap salah satu siswi SMA di Yogyakarta hanya karena 
saling ejek masalah tato bergambar Hello Kitty yang ada ditubuhnya (Viva.co.id, 2015).

Melalui data di atas, peneliti melakukan observasi singkat terhadap beberapa geng tersebut dan menemukan fakta bahwa para pelajar mengikuti geng untuk menunjukkan kejantanannya dan menganggap geng adalah sebuah solidaritas. Salah satu cara untuk menunjukkan solidaritas antar anggota geng adalah dengan merokok. Merokok dianggap sebagai cara untuk mendekatkan diri antara senior dan junior dalam geng di sekolah. Alasan mereka memulai untuk merokok bermacam-macam, ada yang karena penasaran, untuk menunjukkan harga diri, menonton iklan rokok di televisi dan ajakan kakak kelas.

Lingkungan negatif dan sifat labil yang dimiliki para pelajar perokok dalam lingkungan geng ini yang kemudian mempengaruhi bagaimana mereka dalam bertindak, menanggapi dan menyikapi sesuatu salah satunya iklan layanan masyarakat mengenai bahaya merokok. Iklan layanan masyarakat (ILM) merupakan iklan nonkomersial yang disiarkan melalui media massa seperti radio dantelevisidengantujuan menginformasikan dan mendidik masyarakat untuk melakukan perubahan perilaku ke arah yang lebih baik (Masduki, 2007: 234). Selain itu iklan layanan masyarakat juga berfungsi untuk mengubah opini publik dan meningkatkan kesadaran terhadap suatu masalah (Advertising.about. com).

Selama ini pemerintah telah gencar mengeluarkan berbagai iklan layanan masyarakat mengenai bahaya merokok dalam bentuk spanduk, flyer dan baliho. Peringatan tersebut ternyata masih belum mampu menyadarkan audiens iklan perokok termasuk di dalamnya para pelajar perokok khususnya yang ada dalam lingkungan geng di sekolahnya. Maka dari itu, pada November 2014 pemerintah melalui Departemen Kesehatan meluncurkan iklan layanan masyarakat berjudul "Berhentilah Menikmati Rokok Sebelum Rokok Menikmati Anda” yang ditayangkan di beberapa stasiun televisi nasional (Depkes.go.id, 2014). Berikut potongan gambar dalam iklan layanan masyarakat "Berhentilah Menikmati Rokok Sebelum Rokok Menikmati Anda”:
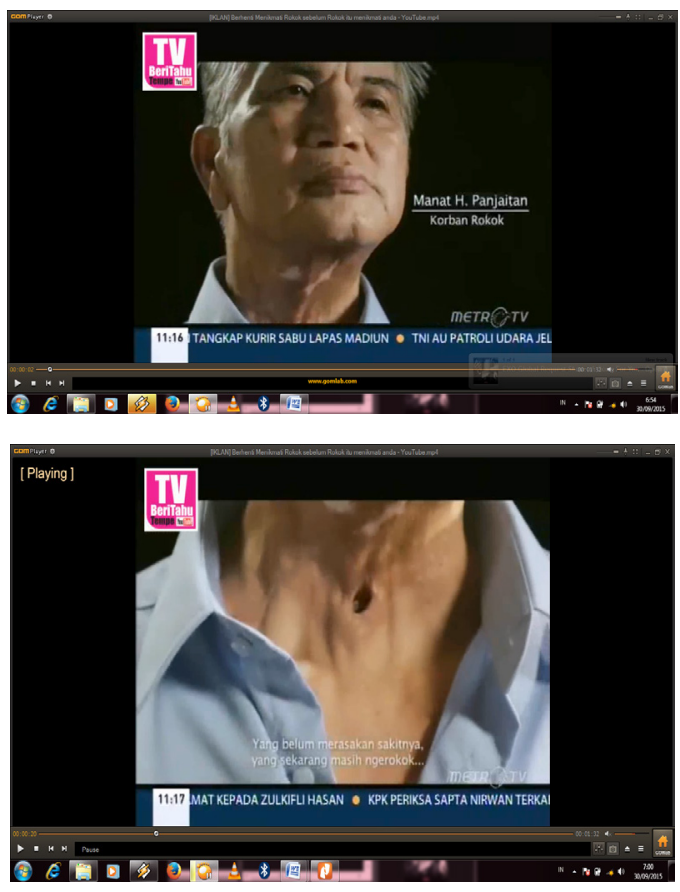

Dalam iklan layanan masyarakat "Berhentilah Menikmati Rokok Sebelum Rokok Menikmati Anda" menampilkan testimoni dari Manat Hiras Panjaitan salah seorang korban rokok yang menderita kanker tenggorokan. Melalui iklan layanan masyarakat ini pemerintah menyampaikan pesan berbentuk ancaman dari bahaya merokok sehingga harapannya para pelajar perokok dapat berhenti mengonsumsi rokok. Hanya saja ini bukan hal yang mudah karena lingkungan memberi pengaruh terbesar terhadap bagaimana audiens memahami iklan tersebut, termasuk juga para pelajar. Oleh karena itu penelitian ini dilakukan untuk menjawab pertanyaan bagaimana pelajar perokok di lingkungan geng di Daerah Istimewa Yogyakarta (DIY) meresepsi pesan iklan dalam iklan layanan masyarakat "Berhentilah Menikmati Rokok Sebelum Rokok Menikmati Anda" oleh Kementerian Kesehatan Republik Indonesia melalui televisi.

\section{KAJIAN PUSTAKA}

Griffin dan Ronald J. Ebert (2007) membagi pesan iklan menjadi tiga bentuk yaitu pesan iklan persuasif, pesan iklan perbandingan dan pesan iklan pengingat. Berdasarkan dari tiga bentuk pesan iklan yang dijelaskan oleh Griffin dan Ronald 
J. Ebert di atas, maka pesan iklan layanan masyarakat memiliki bentuk persuasif. Sifat persuasif dari pesan iklan layanan masyarakat bisa berbentuk ajakan, larangan dan ancaman (Perloff, 2010). Pesan iklan dibuat untuk membujuk audiens agar menggunakan produk yang ditawarkan, hanya saja khalayak kritis tidak semudah itu mengartikan pesan iklan sebagai ajakan membeli. Perbedaan strata pendidikan dan lingkungan akan sangat mempengaruhi audiens dalam memahami pesan iklan (Palupi\&Teguh, 2006: 153).

Karakter kritis dalam hal memilih media dan memaknai pesan media juga terdapat di diri kaum muda, termasuk pelajar. Pelajar sebagai salah satu kelompok audiens aktif diasumsikan dapat memilih perangkat media sekaligus konten informasi yang diinginkan sehingga relevan dengan kajian teoritik uses and gratifications dan teori resepsi. Teori uses and gratifications ialah teori yang menjelaskan bahwa audiens secara aktif mencari media tertentu dan muatan (isi) tertentu untuk menghasilkan kepuasaan tertentu (West\&Turner, 2007:99). Sementara teori resepsi menjelaskan bahwa audiens memaknai teks media dengan cara berbedabeda berdasarkan faktor psikologis dan sosiologis pada tiap-tiap individu (Staiger, 2005:4).

Kajian resepsi juga memperkuat teori audiens aktif, uses and gratification. Stuart Hall menjelaskan ada tiga posisi audiens dalam meresepsi atau memaknai pesan yang disampaikan oleh media berdasarkan perbedaan status sosial, tingkat pendidikan, kerangka referensi dan pengalaman (Stuart Hall, 1974). Tiga posisi audiens tersebut adalah dominant-hegemonic, negotiated dan oppositional.

Audiens dalam posisi dominant-hegemonic menerima pesan media dengan menerjemahkan dan menerima wacana sama persis dengan wacana yang dibawakan oleh media. Audiens tidak memberikan 'perlawanan' terhadap pesan yang disampaikan oleh media. Hal tersebut muncul karena audiens dalam posisi ini cenderung tidak memiliki banyak pengetahuan atau referensi mengenai perilaku media dalam merepresentasikan pesan. Posisi ini menganggap bahwa audiens bersifat pasif sehingga mudah dipengaruhi oleh pesan yang disampaikan oleh media.

Posisi kedua yang terbentuk pada audiens dalam meresepsi pesan adalah negotiated. Dalam posisi ini audiens melakukan negosiasi antara makna yang disampaikan oleh pesan di media dengan makna yang tercipta dalam benaknya. Pesan yang disampaikan oleh media tidak di terima begitu saja oleh audiens. Audiens menerima pesan yang disampaikan oleh media tetapi berpikir kembali apakah wacana tersebut sesuai dengan apa yang diyakini atau tidak.

Bentuk ketiga dari posisi audiens dalam meresepsi pesan adalah oppositional, yaitu audiens memahami pesan media namun tidak menerima wacana yang disampaikan. Posisi ini merupakan posisi audiens yang cenderung memiliki pengetahuan dan wawasan mengenai apa yang disampaikan oleh media dengan realitas yang ada. Audiens dalam posisi oppositional membaca pesan dari posisi yang berlawanan sehingga sering dianggap sebagai audiens bersifat kritis, dimana mereka tidak percaya begitu saja oleh wacana yang disampaikan dan menelaah kembali mengenai kebenaran pesan yang disampaikan oleh media tersebut.

Selanjutnya konsep mengenai kelompok geng pelajar dan lingkungan digambarkan sebagai dua hal yang saling berkaitan satu sama lain. Di mana kelompok pelajar ada karena pengaruh lingkungan dan lingkungan terbentuk karena keberadaan kelompok pelajar. Pelajar yang bersifat labil emosi akan sangat mudah untuk masuk ke dalam kelompok pelajar yang tidak baik (Azca et.al, 2013). Hal ini tentu berbeda dengan pelajar yang berada di lingkungan yang positif sehingga mereka akan berkumpul bersama teman-teman lainnya yang juga sama-sama melakukan aktivitas positif. Azca (et.al, 2013) juga menambahkan jika keluarga memiliki peran kuat dalam pembentukan karakter para pelajar, namun lingkungan di mana mereka berada akan lebih menentukan kelompok pelajar seperti apa yang mereka pilih. 


\section{METODE}

Penelitianiniadalahpenelitian kualitatif, yaitu penelitian yang mengemukakan gambaran dan atau pemahaman (understanding) mengenai bagaimana dan mengapa suatu gejala atau realitas itu terjadi (Pawito, 2007: 36). Penelitian kualitatif yang mengkaji tentang khalayak dan media adalah analisis resepsi. Analisis resepsi memandang bahwa audiens mampu menyeleksi dalam arti memaknai dan memilih makna dari teks berdasar posisi sosial budaya yang mereka miliki (Bertrand\&Hughes, 2005: 39). Analisis resepsi merupakan kajian yang erat kaitannya dengan encoding-decoding pesan. Dalam prosesnya, decoding pesan yang dihasilkan oleh audiens akan berbeda satu sama lain bergantung pada referensi dan pengalaman yang dimilikinya (Hall, 1980). Referensi merupakan daftar bacaan untuk memudahkan seseorang melihat situasi, fenomena dan keadaan sosial yang kemudian akan dibandingkan dengan apa yang selama ini dipelajari guna membentuk konsepkonsep dalam diri (Tasmara, 2006: 156).

Obyek dari penelitian iniadalahtayangan iklan layanan masyarakat "Berhentilah Merokok Sebelum Rokok MenikmatiAnda” di media televisi, sementara subyek penelitian ialah praktek resepsi pesan iklan dalam iklan layanan masyarakat "Berhentilah Merokok Sebelum Rokok Menikmati Anda” yang dilakukan oleh pelajar perokok di lingkungan geng di Daerah Istimewa Yogyakarta (DIY). Penelitian ini dilakukan pada tahun 2015 di Yogyakarta dengan mengambil empat informan yang terdiri dari tiga laki-laki dan satu perempuan yaitu Agung Prasetyo (pelajar SMAN 6 Yogyakarta; geng yang diikuti: GNB, Guyub Ngisor Beringin); Aditya Rio (siswa binaan PSBR (Panti Sosial Bina Remaja), Sleman Yogyakarta; geng yang diikuti: REMBOL (Kere/miskin dan nggerombol/ berkumpul)); Usamah Jihad (pelajar SMK Negeri 2 Yogyakarta; geng yang diikuti: STEMSA (Squad Team Jetis Satu)) dan Eunike Gita (pelajar SMA Mandhala Bakti Sleman, Yogyakarta); geng yang diikuti: HELLO KITTY))

Pemilihan informan dilakukan dengan cara melakukan observasi singkat dengan melihat elemen-elemen persamaan dan perbedaan yang dimiliki tiap-tiap informan. Karakteristik yang dimiliki oleh informan antara lain adalah perokok aktif, bersekolah di Daerah Istimewa Yogyakarta, merupakan anggota geng dan menonton tayangan iklan layanan masyarakat "Berhentilah Menikmati Rokok Sebelum Rokok Menikmati Anda” di media televisi. Sementara tiap-tiap informan memiliki perbedaan dalam asal sekolah, asal geng, kebiasaan bermedia dan latar belakang keluarga yang mencakup status ekonomi, riwayat keluarga dalam merokok serta respon keluarga terhadap aktivitas merokok. Bagi peneliti, elemen-elemen pembeda ini menjadi sangat penting untuk dipertimbangkan saat menentukan informan agar hasil yang diperoleh lebih variatif.

Data yang sudah diperoleh selanjutnya dianalisis secara interpretif guna memahami praktek resepsi audiens terhadap iklan layanan masyarakat di media televisi. Proses analisis data akan diawali dengan melakukan interpretasi pada wawancara mendalam individu (in-depth interview) dan teknik analisis data yang digunakan adalah teknik triangulasi data. Teknik triangulasi data dilakukan untuk memperkuat data yang diperoleh melalui berbagai teknik pengumpulan data (Dharma, 2011).

Dalam penelitian ini sumber data dan teknik pengumpulan data yang digunakan dalam triangulasi data yaitu data informan yang diperoleh dari opini informan dalam praktek wawancara mendalam individu (in-depth interview). Sementara limitasi penelitian ialah bagaimana pelajar perokok di lingkungan geng di Daerah Istimewa Yogyakarta (DIY) meresepsi pesan iklan dalam iklan layanan masyarakat "Berhentilah Menikmati Rokok Sebelum Rokok Menikmati Anda” oleh Kementerian Kesehatan Republik Indonesia melalui televisi.

\section{HASIL DAN PEMBAHASAN}

\section{Nilai atau Makna Merokok}

Membahas tentang makna merokok, Agung, Rio dan Nike adalah tiga informan yang mengaku merokok adalah bentuk ke- 
wajiban yang harus dilakukan, apalagi jika sedang berkumpul bersama teman geng. Selanjutnya, oleh Nike merokok dimaknai sebagai salah satu cara menunjukkan eksistensi sebagai perempuan perokok dan persahabatan antar perokok perempuan terutama sesama anggota geng HELLO KITTY. Menurut Nike, kehadiran perokok perempuan saat ini ialah hal yang wajar dan tidak perlu lagi diperdebatkan. Ia juga bercerita bahwa sebagai sosok perempuan, dirinya ingin dianggap setara dengan lelaki yang juga perokok.

Sudut pandang berbeda disampaikan oleh informan bernama Usamah. Usamah yang mulanya adalah perokok berat dan sekarang sudah mulai mengurangi konsumsi rokoknya ini menjelaskan bahwa dulu saat menjadi perokok berat dirinya memaknai rokok sebagai caranya mengekspresikan kebebasan dan persahabatan. Dengan merokok, Usamah merasa lebih dianggap dalam suatu lingkungan tertentu. Hanya saja pemikiran tersebut menghilang seiring berjalannya waktu terutama usai kakek kandungnya yang seorang perokok berat meninggal terserang kanker paru-paru.

\section{Aktivitas Merokok dan Keberadaan di Lingkungan Geng}

Keempat informan juga memiliki perbedaan dalam hal latar belakang awal mula merokok termasuk motivasi merokok dan intensitas merokok. Agung dan Nike adalah dua informan yang mulai merokok sejak duduk di bangku kelas 6 SD. Informan lain yang juga sudah lama mulai merokok adalah Usamah. Meski tidak sama dengan Agung dan Nike yang memulai merokok di bangku SD, dirinya mulai merokok sejak kelas 1 SMP. Pengalaman berbeda muncul dari Rio yang mulai merokok sejak kelas 3 SMP. Sama dengan ketiga informan sebelumnya, Rio mengaku bahwa awal ia memutuskan merokok pada saat itu bukan karena pengaruh tayangan iklan rokok. Iklan rokok hanya sebatas memberi referensi merek rokok dan informasi bahaya merokok.

Awal mula merokok, informan Agung mengaku ditawari teman sekolahnya. Ia menambahkan cerita mengenai manfaat iklan rokok sebagai bahan referensi dalam mengenali beberapa merek rokok lain dan juga memberi informasi berupa peringatan tentang bahaya yang ditimbulkan akibat merokok. Sementara Rio dipengaruhi oleh ajakan teman satu geng REMBOL yang diikutinya dan Nike memutuskan menjadi perokok karena penasaran usai melihat perokok di pinggir jalan. Informan Usamah justru mengungkapkan hal lain di mana dirinya termovitasi menjadi perokok karena pengaruh keluarganya.

Data lain yang diperoleh peneliti juga termasuk intensitas mengonsumsi rokok keempat informan di mana Agung, Nike dan Rio tergolong dalam perokok berat. Di sisi lain Usamah sudah mulai mengurangi jumlah rokok yang dikonsumsinya. Mengenai korelasinya dengan lingkungan geng, keempat informan juga menjelaskan jika kehadiran teman-teman satu geng turut mempengaruhi kebiasaan merokok. Agung, Rio, Usamah dan Nike kompak menganggap aktivitas merokok sebagai salah satu bentuk persahabatan dan solidaritas.

\section{Respons terhadap Kampanye Anti Rokok}

Agung, informan yang mengaku merokok sejak kelas 6 SD bercerita jika kampanye anti rokok akan kalah dengan pola pikir tiap-tiap manusia. Menurut Agung, pemikiran yang muncul dari dalam diri juga turut menjadi faktor mengapa sampai saat ini usaha pemerintah dalam menanggulangi masalah perokok masih belum berjalan. Ia juga menambahkan asumsinya jika merokok hanya menjadi satu alasan saja dibalik kematian seorang perokok.

Pendapat lain disampaikan oleh Rio dan Nike. Sebagai dua pelajar penghuni PSBR (Panti Sosial Bina Remaja) mereka berdua sering mendapatkan sosialisasi tentang kesehatan dan perkembangan remaja seperti bahaya narkoba, seks bebas dan bahaya merokok dari pihak Dinas Kesehatan Kabupaten Sleman, Yogyakarta. Menurut mereka berdua, sosialisasi tentang bahaya merokok yang telah diberikan men- 
jadi tidak berfungsi ketika dihadapkan dengan naluri dan keinginan merokok yang terkadang tidak bisa dipungkiri. Sementara sudut pandang lain dalam mengkritisi kampanye anti rokok yang dicanangkan oleh pemerintah disampaikan oleh Usamah. Dirinya menjelaskan bahwa pemerintah Indonesia tidak konsisten dalam menangani masalah perokok.

\section{Perilaku Bermedia}

Sebagian besar informan menggunakan smartphone yang terhubung internet untuk mencari informasi yang lebih luas dan berkomunikasi dengan teman-temannya, tetapi juga tidak sepenuhnya meninggalkan media televisi. Televisi masih menjadi media yang dipilih oleh informan untuk mencari hiburan dan juga untuk sekedar menemani waktu senggang. Keempat informan juga menjelaskan bahwa pemilihan media yang digunakan didasari oleh motivasi dan tujuan apa yang akan mereka capai. Oleh karenanya, Agung, Rio, Usamah dan Nike sesuai dengan teori uses and gratifications dimana mereka dapat memilah dan memilih media mana yang dikonsumsi sesuai kebutuhan dan tujuan yang dicapai. Keempat informan mengonsumsi televisi dan smartphone yang terhubung internet dengan cara berbedabeda. Agung menonton televisi untuk memenuhi keinginannya menonton hiburan, sementara Usamah mengonsumsi televisi untuk menonton siaran berita. Sementara Rio dan Nike adalah dua informan yang menjadikan televisi sebagai teman di saat mereka merasa bosan.

\section{Pemaknaan terhadap Iklan Layanan Masyarakat "Berhentilah Menikmati Rokok Sebelum Rokok Menikmati Anda"}

Sebagai anggota geng, keempat informan mengaku bahwa keberadaannya di geng juga turut mempengaruhi bagaimana mereka memahami iklan layanan masyarakat "Berhentilah Menikmati Rokok Sebelum Rokok Menikmati Anda” di media televisi. Agung dan Usamah misalnya, sebagai pelajar yang mengikuti geng di sekolahnya ini memiliki intensitas yang cukup tinggi dilihat dari waktu berkumpul dengan teman-teman gengnya. Intensnya pertemuan tersebut yang membuat mereka lebih sering berinteraksi langsung dengan teman-teman geng untuk sekedar membicarakan permasalahan seharihari termasuk masalah rokok di dalamnya.

Agung, menyampaikan pendapatnya tentang tayangan iklan layanan masyarakat "Berhentilah Menikmati Rokok Sebelum Rokok Menikmati Anda” yang sama sekali tidak sesuai dengan kenyataan dan terkesan terlalu berlebihan ini menjelaskan beberapa teman satu gengnya yang menonton iklan tersebut juga memiliki kesamaan pendapat. Lain halnya dengan Usamah yang bercerita bahwa keberadaan di geng STEMSA tidak begitu banyak mempengaruhi dirinya dalam memaknai pesan iklan pada iklan layanan masyarakat "Berhentilah Menikmati Rokok Sebelum Rokok Menikmati Anda”. Usamah telah membulatkan tekatnya untuk mengurangi konsumsi rokok karena tahu betul bagaimana bahaya rokok akibat pengalaman pribadinya ini bercerita bahwa masih banyak teman satu gengnya yang tidak menghiraukan peringatan bahaya merokok terutama tayangan iklan layanan masyarakat "Berhentilah Menikmati Rokok Sebelum Rokok Menikmati Anda" di media televisi.

Dalam hal memaknai pesan iklan pada tayangan iklan layanan masyarakat "Berhentilah Menikmati Rokok Sebelum Rokok Menikmati Anda”, Usamah memiliki kesamaan dengan realitas yang dia alami. Sementaraketerkaitannyadenganlingkungan geng, menurut Usamah beberapa temanteman di gengnya sebenarnya paham dengan maksud dari tayangan iklan tersebut namun beranggapan bahwa selama ini peringatan bahaya merokok sangat membosankan dan terkesan berlebihan termasuk tayangan Iklan layanan masyarakat "Berhentilah Menikmati Rokok Sebelum Rokok Menikmati Anda". Ia menjelaskan jika dalam memaknai pesan iklan pada iklan layanan masyarakat "Berhentilah Menikmati Rokok Sebelum Rokok Menikmati Anda" dirinya tidak begitu terpengaruh oleh keberadaan teman-teman 
geng STEMSA karena berdasarkan pengalaman pribadinya, dia tahu persis bahwa merokok dapat menyebabkan kanker. Meski paham dengan isi iklan, sampai saat ini dirinya masih menjadi perokok aktif karena ajakan teman geng.

Berbeda dengan Agung dan Usamah, Rio dan Nike adalah informan yang berasal dari geng di lingkungan bermain. Selain sebagai seorang pelajar, mereka berdua juga merupakan penghuni Panti Sosial Bina Remaja (PSBR) guna rehabilitasi. Dua alasan tersebut membuat Rio dan Nike lebih jarang bertemu dengan teman-teman di gengnya dibandingkan dengan kedua informan sebelumnya yaitu Agung dan Usamah.

Rio menjelaskan bahwa pemaknaannya terhadap iklan layanan masyarakat "Berhentilah Menikmati Rokok Sebelum Rokok Menikmati Anda" juga dipengaruhi oleh teman-teman di geng yang diikutinya di desa yaitu geng REMBOL. Menurut Rio, tidak banyak teman satu gengnya yang pernah menonton tayangan iklan layanan masyarakat "Berhentilah Menikmati Rokok Sebelum Rokok Menikmati Anda" di media televisi karena mereka cenderung jarang mengakses televisi dan memilih menggunakan smartphone. Rio bercerita bahwa beberapa teman gengnya yang pernah menonton tayangan iklan tersebut berpendapat jika iklan terkesan lebih nyata dibanding peringatan di kemasan rokok. Mereka juga menjelaskan iklan tersebut hanya ditujukan bagi perokok aktif yang sudah lama merokok dan sudah berumur sehingga mereka beranggapan bahwa selagi masih muda, merokok tidak masalah. Berdasar dari pendapat teman dalam gengnya tersebut, Rio meragukan kebenaran dampak merokok seperti timbulnya kanker tenggorokan seperti yang ditayangkan di dalam iklan layanan masyarakat.

Informan Rio dalam memaknai pesan iklan pada tayangan iklan layanan masyarakat "Berhentilah Menikmati Rokok Sebelum Rokok Menikmati Anda” cenderung dipengaruhi oleh keberadaannya di geng. Keraguan yang dia alami sama dengan pendapat dari teman-teman di gengnya. Teman- teman satu geng Rio menjelaskan bahwa iklan tersebut hanya ditujukan bagi perokok aktif yang sudah lama merokok dan berusia tua sehingga merokok tidak akan menimbulkan masalah besar bagi anak muda. Berdasar dari pendapat teman dalam gengnya tersebut, Rio menjadi tidak yakin apakah benar seorang perokok nantinya akan menderita penyakit kanker tenggorokan seperti apa yang ditayangkan dalam iklan.

Sementara informan Nike, seorang perokok perempuan yang juga anggota geng di lingkungan bermainnya yaitu geng HELLO KITTY bercerita bahwa temanteman dalam gengnya tersebut juga turut mempengaruhi bagaimana ia memaknai pesan iklan dalam tayangan iklan layanan masyarakat "Berhentilah Menikmati Rokok Sebelum Rokok Menikmati Anda”. Menurut Nike, teman-temannya pernah menonton tayangan iklan tersebut di televisi dan di youtube dan menganggap iklan tersebut terkesan memberi informasi dengan cara mengancam. Maksudnya adalah iklan ini berbeda dengan peringatan bahaya merokok di kemasan yang sekedar memberi informasi berupa tulisan dan gambar, sementara tayangan iklan layanan masyarakat "Berhentilah Menikmati Rokok Sebelum Rokok Menikmati Anda" langsung memperlihatkan bagaimana seorang penderita kanker tenggorokan bercerita tentang bahaya dari aktivitas merokok. Semua teman Nike di dalam geng tersebut setuju dengan wacana yang dilontarkan dalam iklan sekaligus percaya bahwa pada saatnya nanti para perkok akan menderita berbagai macam penyakit. Kepercayaan ini muncul karena Nike dan teman-temannya sering menemui kawan atau orang-orang yang mulanya perokok pada akhirnya menderita penyakit yang menyerang saluran pernafasan. Hanya saja, mereka tidak bisa menolak untuk tidak merokok saat sedang berkumpul bersama.

Informan Nike juga menjelaskan aktivitas merokok adalah kewajiban yang harus dilakukan oleh dirinya dan temanteman satu gengnya. Bagi Nike dan temantemannya sesama perokok wanita, merokok adalah cara mereka untuk menunjukkan 
eksistensi sebagai perempuan perokok dan persahabatan antar perokok perempuan. Dirinya juga mengaku canggung jika sedang berkumpul bersama teman-teman satu gengnya tanpa melakukan aktivitas rokok. Dalam hal memaknai isi pesan iklan dalam tayangan iklan layanan masyarakat "Berhentilah Menikmati Rokok Sebelum Rokok Menikmati Anda”, Nike cenderung dipengaruhi oleh keberadaannya dalam geng. Dirinya menaruh kepercayaan terhadap pesan iklan karena Nikedan teman-temannya dalam geng tersebut sering menemui kawan atau orang-orang yang mulanya perokok pada akhirnya menderita penyakit yang menyerang saluran pernafasan. Sehingga ia semakin yakin bahwa kemunculan penyakit yang disebabkan akibat merokok memang benar-benar nyata.

\section{Resepsi Pesan Iklan}

Menjawab pertanyaan penelitian yaitu bagaimana pelajar perokok di lingkungan geng di Daerah Istimewa Yogyakarta (DIY) meresepsi pesan iklan dalam iklan layanan masyarakat berjudul "Berhentilah Menikmati Rokok Sebelum Rokok Menikmati Anda”, maka secara keseluruhan keempat informan paham dengan pesan yang disampaikan dalam iklan layanan masyarakat "Berhentilah Menikmati Rokok Sebelum Rokok Menikmati Anda" di media televisi. Mereka semua mengerti bahwa dalam iklan tersebut, audiens diajak untuk sadar bahwa merokok dapat menyebabkan kanker tenggorokan dan berharap audiens dapat sesegera mungkin berhenti dari aktivitas merokoknya.

Masalah yang ditemukan dalam temuan penelitian ini ialah semua audiens yang memaknai pesan iklan belum tentu menerima wacana yang disampaikan. Ada beberapa informan yang menolak wacana tersebut namun adapula yang menerimanya. Fenomena tersebut sesuai dengan teori resepsi yang dijadikan rujukan penelitian ini. Audiens dalam praktek resepsi adalah audiens aktif di mana mereka merupakan penonton yang mampu bernegosiasi dengan pesan yang disampaikan oleh media. Sebelum menjadi audiens aktif, para audiens mampu memilah dan memilih media yang digunakan sesuai kebutuhan dan tujuan. Hal tersebut juga sesuai dengan teori uses and gratifications dibuktikan dengan bagaimana kebiasaan bermedia keempat informan.

Meski sama-sama mengonsumsi televisi dan smartphone, keempat informan memiliki tujuan dan cara yang berbeda-beda dalam mengonsumsi media. Agung menonton televisi untuk memenuhi keinginannya menonton tayangan hiburan sementara Usamah mengonsumsi televisi untuk menonton siaran berita. Kemudian Rio dan Nike adalah dua informan yang menjadikan televisi sebagai teman di waktu senggang.

Selain televisi, media lain yang juga diakses oleh keempat informan adalah smartphone. Dibandingkan dengan televisi, Rio dan Nike lebih banyak menghabiskan waktunya untuk mengakses internet melalui smartphone. Rio menggunakan smartphone untuk berkomunikasi dengan teman-temannya melalui jejaring sosial Facebook. Sementara Nike menggunakan smartphone untuk berkomunikasi dengan teman-temannya melalui aplikasi pesan singkat seperti BBM dan WhatsApp. Menurut mereka berkomunikasi melalui fasilitas chat dan jejaring sosial lebih mudah dan murah dibandingkan berkirim pesan singkat.

Selanjutnya masuk dalam konsep audiens aktif, keempat informan adalah audiens yang masuk dalam ranah audiens aktif di mana mereka bisa bernegosiasi dengan pesan media. Fenomena ini tentu bertolak belakang dengan teori jarum suntik yang menjelaskan bahwa pesan media disuntikkan pada audiens dan mereka menerima begitu pesannya. Dalam sudut pandang audiens aktif, audiens adalah penonton yang bernegosiasi dengan pesan media. Pernyataan tersebut sama halnya dengan apa yang peneliti temukan pada keempat informan dalam penelitian ini.

Selanjutnya, hal yang menunjukkan sifat aktif dari diri audiens adalah ketika mereka menanggapi kampanye anti rokok dan iklan layanan masyarakat bahaya merokok secara umum yang selama ini dicanangkan oleh pemerintah. Keempat informan se- 
pakat bahwa berhenti merokok adalah masalah kesadaran. Jadi, terkadang apa yang dilakukan pemerintah dengan segala kampanye anti rokoknya akan menjadi sia-sia jika para perokok tidak sadar dengan bahaya merokok itu sendiri.

Keempat informan mengetahui peringatan, kampanye dan iklan layanan masyarakat bahaya merokok digunakan pemerintah sebagai cara untuk mengurangi angka perokok sekaligus menyadarkan para perokok bahwa merokok dapat mengganggu kesehatan. Namun kembali lagi pada konsep audiens aktif, tidak semua informan menerima wacana tersebut dan kemudian mengubah sikapnya dalam merokok. Agung, Rio dan Nike bernegosiasi dengan dirinya sendiri bahwa mereka tahu bahaya merokok tetapi berpikir bahwa merokok adalah masalah keinginan dan naluri untuk memenuhinya. Berbeda dengan Usamah, yang mulai berkeinginan berhenti merokok dengan mengurangi jumlah rokok yang dikonsumsi karena pengaruh tayangan kampanye bahaya merokok dan juga karena pengalaman pribadinya terhadap sang kakek yang seorang perokok meninggal akibat kanker paru paru. Kemudian setelah mereka bisa bernegosiasi dengan pesan media, peneliti selanjutnya menganalisa adanya perbedaan pemaknaan pada tiap-tiap audiens berdasarkan latar belakang yang mereka miliki.

Teori resepsi sebagai studi tentang audiens aktif memandang bahwa audiens mampu selektif dalam memaknai dan memilih makna dari teks berdasar posisi sosial budaya yang mereka miliki. Dalam kajian resepsi, Stuart Hall memetakan terdapat tiga posisi audiens dalam meresepsi pesan yang disampaikan media yaitu dominanthegemonic, negotiated dan oppositional. Perbedaan posisi ini dipengaruhi oleh cara pandang audiens pada pesan iklan yang dipengaruhi perbedaan latar belakang yang dimiliki tiap-tiapinforman. Berkaitan dengan subyek penelitian yaitu pesan iklan dalam iklan layanan masyarakat "Berhentilah Menikmati Rokok Sebelum Rokok Menikmati Anda", peneliti juga menganalisa bagaimana latar belakang mempengaruhi pemaknaan informan pada teks media. Setelah itu, peneliti memetakan tiap-tiap informan ada di posisi audiens yang seperti apa.

Dimulai dari informan Agung, dirinya menganggap tayangan iklan layanan masyarakat"BerhentilahMenikmati RokokSebelum Rokok Menikmati Anda" terlalu berlebihan dan tidak sesuai dengan kenyataan. Pemikiran ini muncul karena Agung menyaksikan sendiri bagaimana keluarganya yang perokok (ayah, kakek, paman, dan keponakan) sampai saat ini keadaannya masih sehatsehat saja. Dari situlah Agung berpikir bahwa kanker tenggorokan dan kematian tidak semata-mata disebabkan oleh merokok. Ia meragukan fakta yang disampaikan dalam konten iklan layanan masyarakat bahaya merokok.

Tidak hanya itu, Agung yang merupakan anggota geng di sekolahnya bercerita bahwa iklan layanan masyarakat "Berhentilah Menikmati Rokok Sebelum Rokok Menikmati Anda" sama sekali tidak memberikan pengaruh perubahan perilaku pada dirinya dan teman-temannya sesama anggota geng. Ia menjelaskan jika usianya yang masih muda rentan terjangkit penyangkit tenggorokan yang kerap ditayangkan dalam iklan-iklan layanan masyarakat bahaya merokok. Namun Agung mengaku merasa kurang nyaman dengan visualisasi yang ditayangankan iklan layanan masyarakat "Berhentilah Menikmati Rokok Sebelum Rokok Menikmati Anda", tetapi kurang nyamannya visualisasi iklan tidak menyurutkan keinginannya untuk merokok bersama teman-teman satu gengnya. Ketika sedang merokok dengan teman-teman satu gengnya, Agung seakan dibuat lupa dengan gambaran-gambaran iklan yang sebelumnya pernah dilihat.

Informan Agung dapat memaknai maksud dari tayangan iklan layanan masyarakat "Berhentilah Menikmati Rokok Sebelum Rokok Menikmati Anda" yaitu memberi penjelasan pada perokok bahwa merokok dapat menyebabkan kanker tenggorokan dengan menyertakan testimoni salah seorang penderita kanker tenggorokan 
tetapi tidak kemudian berhenti merokok. Dengan begitu, Agung masuk dalam ranah audiens oppositional, di mana ia paham dengan pesan yang disampaikan dalam iklan namun menolak wacana tersebut. Selain itu, tidak ada perubahan perilaku dalam diri Agung dan dirinya tetap melanjutkan aktivitas merokoknya.

Selanjutnya adalah informan bernama Rio yang juga memahami iklan layanan masyarakat "Berhentilah Menikmati Rokok Sebelum Rokok Menikmati Anda" sebagai iklan yang dibuat untuk menyadarkan para perokok agar berhenti merokok dengan menampilkan testimoni langsung dari penderita kanker tenggorokan. Ia juga mengaku tidak nyaman dengan visualisasi iklan yang memperlihatkan tenggorokan korban rokok, Manat H. Panjaitan. Menurut Rio, testimoni langsung yang disampaikan oleh korban rokok membuat tayangan iklan tersebut lebih nyata dibandingkan sekedar tulisan bahaya merokok yang tertera di kemasan produk rokok.

Sama seperti Agung, Rio juga termasuk informan yang paham dengan pesan iklan namun tidak langsung dapat menyadarkannya akan bahaya merokok. Dirinya menaruh sedikit ketidakpercayaan, apakah benar seorang perokok nantinya akan menderita penyakit kanker tenggorokan seperti apa yang ditayangkan dalam iklan. Pengaruh latar belakang keluarga juga menjadi alasan mengapa dirinya masih belum mempercayai bahwa merokok dapat menimbulkan gangguan kesehata. Rio bercerita bahwa ayahnya yang dulu adalah seorang perokok berat telah berhenti total. Meski tahu Ayahnya berhenti merokok karena alasan kesehatan dan keuangan, Rio tetap berpikiran bahwa penyakit bahaya merokok akan datang pada orang yang sudah lama merokok dan berumur tua. Sementara Rio menganggap dirinya sebagai sosok yang masih muda, sehingga dirinya tidak akan terkena penyakit tersebut.

Rio mengetahui bahwa iklan layanan masyarakat "Berhentilah Menikmati Rokok Sebelum Rokok Menikmati Anda" dirancang untuk menyadarkan para perokok agar berhenti merokok dengan menampilkan testimoni langsung dari penderita kanker tenggorokan. Tetapi, Rio menolak wacana tersebut karena dirinya mengartikan iklan dengan sudut pandang berbeda sesuai pengalaman yang dialaminya selama ini. Di mana, menurut Rio penyakit bahaya merokok akan datang pada orang yang sudah lama merokok dan berumur tua. Meskipun kondisi fisiknya menurun, menurut Rio, ayahnya tersebut hanya mengalami batukbatuk dan gigi yang berubah kuning, tidak separah apa yang di tayangkan dalam iklan.

Berdasarkan dari cara memaknai iklan, Rio masuk dalam ranah audiens di posisi oppositional di mana dirinya paham dengan pesan yang disampaikan dalam iklan layanan masyarakat "Berhentilah Menikmati Rokok Sebelum Rokok Menikmati Anda" namun menolak wacana tersebut. Selain itu Rio juga tidak mengubah perilaku dan terus melanjutkan merokok bersama teman-teman di asrama maupun saat berkumpul dengan kawan geng REMBOL.

Kemudian informan lain yang juga sama-sama memahami pesan iklan namun tidak mengaplikasikannya dalam kehidupan adalah Nike. Perokok perempuan ini bercerita bahwa ia sempat mengalami rasa takut saat sedang maupun sesudah menonton tayangan iklan layanan masyarakat "Berhentilah Menikmati Rokok Sebelum Rokok Menikmati Anda”. Nike mampu bernegosiasi dengan pesan iklan karena ia percaya bahwa seorang perokok suatu saat nanti akan mengalami berbagai macam gangguan kesehatan, seperti kanker tenggorokan misalnya. Hanya saja menurut Nike, merokok adalah masalah naluri. Sekalipun dirinya percaya bahwa seorang perokok bisa-bisa saja mengalami kanker tenggorokan seperti yang digambarkan dengan iklan namun kepercayaan itu akan kalah dengan keinginannya untuk merokok.

Nike memaknai pesan iklan tersebut hanya sebagai sebuah himbauan yang terkadang tidak sesuai dengan naluri perokok. Ketakutan yang muncul akan hilang seketika jika dirinya sudah terlanjur menghabiskan waktu dengan merokok bersama teman- 
teman satu gengnya. Nike bercerita bahwa hampir mustahil jika ia tidak merokok saat bersama teman-temannya di geng HELLO KITTY. Bagi Nike, merokok adalah cara untuk menunjukkan eksistensi sebagai perempuan perokok dan persahabatan antar perokok perempuan. Menurut Nike, perokok perempuan adalah hal yang wajar dan bukan lagi menjadi hal yang harus diperdebatkan. Nike juga menjelaskan aktivitas merokok ialah bentuk kenyamanan yang dirasakan sekaligus sebagai cara menunjukkan persahabatan antar perokok perempuan.

Melihat bagaimana Nike mengartikan pesan iklan dalam iklan layanan masyarakat "Berhentilah Menikmati Rokok Sebelum Rokok Menikmati Anda”, Nike masuk dalam ranah negotiated audience di mana ia mampu bernegosiasi dengan pesan karena dirinya percaya dengan apa yang disampaikan iklan. Dirinya yakin bahwa suatu saat nanti seorang perokok akan menderita kanker tenggorokan seperti yang ditayangkan dalam iklan. Oleh karenanya wacana di dalam iklan tersebut diterima oleh Nike hanya saja tidak disertai dengan perubahan sikap karena terbukti sampai saat ini ia masih mengonsumsi rokok.

Informan terakhir yang juga dapat memaknai pesan iklan dalam tayangan iklan layanan masyarakat "Berhentilah Menikmati Rokok Sebelum Rokok Menikmati Anda" adalah Usamah. Menurut Usamah, tidakusah diragukan lagi bahwa merokok sebenarnya merusak fisik secara perlahan. Hanya saja kesadaran bahaya merokok sampai saat ini belum bisa diterima dengan baik oleh para perokok. Sama seperti apa yang disampaikan dalam tayangan iklan layanan masyarakat "Berhentilah Menikmati Rokok Sebelum Rokok Menikmati Anda”, Usamah percaya bahwa seorang perokok, siapapun itu dan di usia berapa-pun suatu saat nanti akan mengalami berbagai gangguan kesehatan salah satunya kanker tenggorokan. Ia bisa memaknai pesan iklan tersebut seperti itu karena Usamah menyaksikan salah seorang anggota keluarganya yang seorang perokok berat meninggal karena serangan kanker paru-paru.

Informan Usamah juga bercerita selain karena keberadaan tayangan iklan layanan masyarakat "Berhentilah Menikmati Rokok Sebelum Rokok Menikmati Anda”, kematian salah satu anggota keluarganya karena merokok juga terpaan peringatan bahaya merokok di iklan menjadi alasan lain yang menyadarkan dirinya bahwa merokok bisa membahayakan kesehatan. Oleh karena itu Usamah saat ini dalam proses untuk berhenti mengonsumsi rokok dengan mengurangi jumlah rokok yang dikonsumsi per hari. Dengan kata lain intensitas merokok Usamah berkurang karena pengalaman di masa lalu dan informasi yang ia peroleh dari iklaniklan bahaya merokok. Ia menjelaskan jika kebiasannya merokok dilakukan jika ada keinginan atau sekedar ditawari oleh teman geng STEMSA. Usamah menambahkan ia tidak keberatan jika dalam satu hari tidak mengonsumsi rokok.

Dari data yang diperoleh peneliti, informan Usamah masuk dalam kategori negotiated audience di mana dirinya mampu bernegosiasi dengan isi pesan iklan. Meski ragu dengan keseriusan pemerintah dalam menangani masalah perokok di negera ini, Usamah yakin bahwa tayangan iklan layanan masyarakat "Berhentilah Menikmati Rokok Sebelum Rokok Menikmati Anda” ini dirancang untuk kembali menyadarkan para perokok bahwa merokok membahayakan tubuhnya. Usamah mempercayai wacana yang disampaikan iklan karena pengalaman yang selama ini dia rasakan. Meski sebelumnya sempat ragu dengan ancaman penyakit yang ditayangkan dalam iklan layanan masyarakat "Berhentilah Menikmati Rokok Sebelum Rokok Menikmati Anda”, pada akhirnya Usamah disadarkan akan bahaya merokok setelah meninggalnya anggota keluarganya akibat serangan kanker paruparu. Usamah juga menjadi satu-satunya informan yang berkeinginan untuk perlahanlahan lepas dari kebiasaan merokoknya dengan mengurangi konsumsi rokoknya perlahan.

\section{SIMPULAN}

Keempat pelajar anggota geng yang diambil sebagai informan penelitian me- 
miliki kesamaan kategorisasi yaitu merupakan perokok aktif, bersekolah di Daerah Istimewa Yogyakarta, merupakan anggota geng dan menonton tayangan iklan layanan masyarakat "Berhentilah Menikmati Rokok Sebelum Rokok Menikmati Anda” di media televisi. Sementara perbedaan yang dimiliki adalah latar belakang tiap informan yang dilihat dari asal sekolah termasuk asal geng, latar belakang keluarga yang mencakup riwayat keluarga dalam merokok dan respon keluarga terhadap aktivitas merokok, kemudian status ekonomi, latar belakang awal mula dalam merokok dan kebiasaan dalam bermedia.

Dari penelitian yang telah dilakukan, dua informan berada di posisi audiens dalam meresepsi pesan tipe oppositional karena merasa tidak nyaman dengan visualisasi iklan, namun keduanya menolak wacana tersebut. Sementara dua informan lainnya masuk dalam kategori audiens negotiated di mana mereka bernegosiasi dengan pesan yang diberikan dalam iklan. Dari hasil penelitian yang diperoleh, maka penelitian ini juga memberikan konfirmasi bahwa audiens

Pelajar bukan lagi sekelompok penonton media yang diam dan menerima begitu saja pesan yang disampaikan oleh media, tetapi mereka adalah audiens aktif baik dalam memilih media mana yang akan diakses dan juga aktif dalam mengartikan pesan media terutama iklan. Tidak hanya mampu mengartikan isi pesan, audiens aktif juga bernegosiasi dengan pesan iklan sehingga pada akhirnya akan menghasilkan bentukbentuk audiens yang menerima wacana iklan atau menolak wacana iklan. Perbedaan pemaknaan terhadap pesan iklan sendiri dipengaruhi oleh beberapa hal seperti latar belakang yang dimiliki dan juga lingkungan di mana mereka berada.

Dalam penelitian ini ditemukan data bahwa pelajar yang merupakan anggota geng dapat memaknai pesan iklan yang disampaikan iklan layanan masyarakat "Berhentilah Menikmati Rokok Sebelum Rokok Menikmati Anda” di media televisi. Jika dikaitkan dengan teori resepsi maka dua pelajar anggota geng berada di dalam posisi negotiated audience, sementara dua informan lainnya pada posisi oppositional audience.

\section{SARAN}

Melihat semakin beragamnya audiens, maka sebagai pihak perancang iklan layanan masyarakat yaitu pemerintah disarankan untuk melakukan survei terlebih dahulu sebelum menayangkan suatu iklan. Hal tersebut penting untuk dilakukan agar penayangan iklan lebih fokus menarget siapa audiens yang dituju. Survei tersebut mencakup gambaran tentang target audiens iklan terutama siapa audiens iklan yang akan dituju dan kebiasaan bermedia. Survei mengenai siapa saja target audiens yang akan dituju akan sangat berguna untuk mengelompokkan audiens iklan berdasarkan beberapa kriteria seperti usia dan informasi tentang latar belakang audiens. Dua hal tersebut perlu dipelajari oleh pihak pembuat iklan karena akan mempengaruhi bagaimana audiens dalam merespons dan memahami konten iklan.

Kemudian, survei tentang kebiasaan bermedia juga perlu dilakukan untuk mengetahui media apa yang digunakan, situs apa yang diakses dan kapan media tersebut dikonsumsi oleh target audiens. Dengan melakukan survei tersebut, iklan layanan masyarakat yang diproduksi oleh pemerintah terutama yang mengangkat tema bahaya merokok akan lebih fokus menarget audiens yang dituju dan lebih efisien dalam menyadarkan para perokok bahwa merokok membahayakan tubuhnya dan segera berhenti mengonsumsi rokok.

Rekomendasi kedua ditujukan bagi akademisi ilmu komunikasi khususnya dalam penelitian selanjutnya untuk dapat lebih memperbanyak dan memperdalam penelitian analisis resepsi yang membahas tentang iklan layanan masyarakat. Hal tersebut penting dilakukan karena selama ini fokus penelitian resepsi iklan hanya berada di ranah iklan sebuah produk, sementara kajian resepsi iklan layanan masyarakat masih jarang dilakukan. 


\section{DAFTAR PUSTAKA}

Adiyaningsih, Titik. (2015). Juni 9. Pendamping Psikolog Dinas Kesehatan Kabupaten Sleman. Personal Interview. Sleman.

Advertising.about.com. Public Service Advertising - A Complete Definition of Public Service Advertising. Diakses 11 November 2014 pukul 21:35 WIB dari http://advertising.about.com/od/ advertisingglossary/g/Public-ServiceAdvertising-A-Complete-DefinitionOf-Public-Service-Advertising.html.

Azca, M. Najib.,et.al. (2011). Pemuda Pasca Orba: potret kontemporer pemuda Indonesia. FISIPOL UGM: YouSure.

Azca, M. Najib.,et.al. (2013). Karakteristik Pemuda dan Kecenderungan Perilaku Kekerasan di Kota Yogyakarta dan Surakarta. FISIPOL UGM: YouSure.

Bertrand, Ina \& Peter Hughes. (2005). Media Research Methods: Audience, Institutions, Texts. New York: Palgrave McMillan.

Depkes.go.id. (2014). Menkes Luncurkan Iklan Layanan Masyarakat (ILM) Korban Rokok. Diakses 11 November 2014 pukul 22:00 WIB dari http://www.depkes. go.id/article/view/201410130001/ menkes-luncurkan-iklan-layananmasyarakat-ilm-korban-rokok.html.

Dharma, Christa Adhi. (2011). Maskulinitas Iklan Rokok dalam Sudut Pandang Perempuan: analisis resepsi mahasiswi perokok di Yogyakarta terhadap maskulinitas iklan televisi produk rokok. Yogyakarta: Fakultas Ilmu Sosial dan Politik Universitas Gadjah Mada.

Griffin, Ricky W \& Ronald J. Ebert. (2007). Business: Eighth Edition. Canada: Pearson .

Hall, Stuart. (1974). The Television Discourse-Encoding and Decoding and Decoding. Dalam Studies in Culture: An Introductory Reader (ed.). Ann Gray dan Jim McGuigan. London: Arnold, 1997.
Hall, Stuart. (1980). Encoding/Decoding. London: Hutchison.

Masduki. (2007). Regulasi Penyiaran: Dari Otoriter ke Liberal. Yogyakarta: LKiS

McQuail, Danis. (1997). Audience Analysis. Thousand Oaks: Sage Publications, Inc.

Palupi, Dyah Hasto \& Teguh Sri Pambudi. 2006. Advertising that Sells; strategi sukses membawa merek anda menjadi pemimpin pasar. Jakarta: Gramedia Pustaka Utama.

Pawito. (2007). Penelitian Komunikasi Kualitatif. LKiS: Yogyakarta

Perloff, Richard M. (2010). The Dynamics of Persuasion: Communications and attitudes in the 21st Century; 3 th edition. New York: Routledge.

Staiger, Janet. (2005). Media Reception Studies. New York: New York University Press

Supartiningsih. (2015), Juni 9. Tim Pendamping Kesehatan Reproduksi Puskesmas Sleman. Personal Interview. Sleman.

Tasmara, Toto. (2006). Spiritual Centered Leadership. Jakarta: Gema Insani.

Viva.co.id. (2015). Gadis-Gadis Penyekap Siswi SMA Anggota Geng Hello Kitty. Diakses 31 Mei 2015 pukul 15:30 dari m.news.viva.co.id/news/read/591536gadis-gadis-penyekap-siswi-smaanggota-geng-hello-kitty.

West, Turner \& Lynn H. Turner. (2007). Introducing Communication Theory: Analysis And Application, 3rd ed. New York: McGraw-Hill. 